доктор педагогічних наук, проббесор (Украӥна, Київ, Київський університет ілені Бориса Грінченка, вул. Бульварно-Кудрявська, 18/2)

STEFANIIA YAVORSKA,

doctor of pedagogical sciences, professor (Ukraine, Kyiv, Borys Grinchenko Kyiv University, Bulvarno-Kudriavska str., 18/2)

ORCID: 0000-0003-3136-3894

\title{
Єдність загальнодидактичних принципів у процесі формування мовно-мовленневих компетентностей в учнів початкової та основної школи
}

The Unity of General Didactic Principles in the Process of Formation Linguistic and Speech Competences with Students of Primary and Secondary School

У статті розглянуто проблему формування мовно-мовленневих компетентностей в учнів початкової та основної школи на засадах застосування загальнодидактичних принципів: активності, свідолості, салостійності, науковості, наступності, послідовності, перспективності, систелатичності, доступності, зв'язку теорї з практикою. На основі аналізу наукових джерел викладено авторську методику роботи над засвоєннял теоретичного матеріалу, збагаченнял лексики учнів, виробленнял колунікативних улінь, яка полягає у колплексному підході до навчання з урахуваннял початкового рівня знань і розвитку учнів.

Обгрунтовано актуальність досліджуваної проблели, визначено чинники, які зуловлюють реалізацію дидактичних приниипів. Доведено, що для легкого засвоєння правил та еконолії часу на практичні вправи потрібно використати набуті учняли знання так, шоб вони стали опорою під час опрацювання навчального матеріалу в наступних класах. Визначено летодику роботи з актуалізацї знань учнів у колплексі, доведено ебективність такого навчання. Аргументовано, що опора на всі необхідні засвоєні раніше правила потребує від учителя застосування еббективних методів і прийолів роботи, які залежатилуть від знань учнів, складу класу, улов, у яких педагог проводитиле урок. Реколендовано для закріплення мовного матеріалу з урахуваннял знань і вікових особливостей учнів добирати тексти, використовувати прислів'я, приказки, вірші, різні види диктантів, переказів, ббрагленти літературних творів, художніх мініатюр тощо.

Зроблено висновок, шо вліле застосування приниипів дидактики активізує навчальну діяльність учнів, сприяє мічності знань, розвиває логічну пал'ять, робить навчання иікавил. Різні бборли роботи з текстол забезпечать оволодіння дітьли всіла типали усного $і$ писелного мовлення.

Ключові слова: загальнододактичні приниипи, перспективність, послідовність, наступність, актуалізація, бборлування влінь і навичок, ловна і мовленнєва колпетентності, методи, тексти, активізаиія, гралотне письло.

The article is devoted to the problem of formation linguistic and speech competences with students of primary and secondary school on the basis of the application of general didactic principles of activity, consciousness, self-dependency, progressive movement, sequence, perspectiveness, simplicity, connection of theory and practice, scientific principle, systemic principle. The author's methodology on learning theoretical material, enriching students' vocabulary and developing communicative skills is based on the analysis of scientific sources and presupposes a complex approach to teaching taking into account the initial level of knowledge and development of students.

The actuality of the investigated problem is grounded; the factors which stipulate the realization of didactic principles are determined. It is proved that to master rules easily and to spare time on practical exercises it is necessary to use knowledge acquired by students in the way it (knowledge) can become a scaffold for the material which will be worked through next year. The methods of work on the actualization of students' knowledge in complex is defined; the effectiveness of this teaching is proved. It is reasoned that a scaffold on all needed earlier learned rules requires from a teacher the utilization of effective methods and techniques of work that will depend on the knowledge of students, the class potential; the conditions under which the teacher will conduct a class. For the consolidation of linguistic material with due regard for knowledge and age peculiarities of students it is recommended to select texts, to use proverbs, sayings, poems, different dictations, narrations, fragments of fiction, artistic miniatures and so on. 
The conclusion is made that a capable utilization of didactic principles activates the learning process of students, favors the strength of knowledge, develops logical memory, makes the process of learning interesting. Various forms of work with a text ensures that students master all types of oral and written speech.

Key words: general didactic principles, perspectiveness, sequence, progressive movement, actualization, formation of habits and skills, linguistic and speech competences, methods, texts, activization, literate writing.

Вступ / Introduction. На всіх етапах розвитку освіта і школа, загальноосвітня і вища, разом із суспільством утягуються у смугу кардинальних перетворень і змін. Навчальні заклади здобувають право на самоврядування, самостійне вирішування внутрішнього управління, відповідно до державних критерій і вимог школи отримують авторські програми і підручники, тлумачення основних засад, ідей, теоретичне обгрунтування яких у сукупності мае бути відображено в педагогічних концепціях. У цьому процесі виняткова роль відводиться мовній освіті, державній мові, у процесі навчання якої вчитель, використовуючи новаторські погляди на освіту, іiі реформування, має забезпечити високу грамотність учнів, всебічний мовленнєвий розвиток особистості.

На шляху перебудови школа розв'язуе низку актуальних питань, що вимагають уваги, обговорення і розв'язання. Перед науковою педагогікою, педагогічною практикою виникають нові проблеми: навчити учнів креативно мислити, вчитися самостійно здобувати знання, розвивати пізнавальний інтерес, оскільки завдання вчителя «не вчити, а тільки допомагати вчитися» (Ушинський К., 1949).

Навчання учнів має бути спрямоване на вироблення і розвиток загальнокультурної грамотності, вміння усно і письмово висловлювати думки державною мовою. Діяльнісно-проблемний підхід до організації навчального процесу, робота над підвищенням культури мовлення і грамотності школярів - це мета навчання, на досягнення якої мають бути спрямовані зусилля педагога.

Оскільки засвоєння мовних i мовленневих норм є складним процесом, вивчення сучасної української літературної мови має грунтуватися на дидактичних принципах - активності, свідомості й самостійності, науковості, наступності, послідовності, перспективності, систематичності, доступності, зв'язку теорії з практикою тощо.

Актуальність проблеми, необхідність оббрунтування й подальшого розроблення методики розвитку мовно-мовленневих компетентностей, застосування в системі загальнодидактичних принщипів, що не набуло належного висвітлення в лінгводидактищі, й зумовили вибір теми дослідження.

Мета і завдання / Aim and tasks. Мета дослідження: розробити науково обтрунтовану методику формування мовно-мовленневих компетентностей учнів початкової та основної школи у процесі вивчення української мови на засадах едності загальнодидактичних принщипів.

Завдання статті: а) обгрунтувати лінгвістичні та методичні умови вивчення мовного матеріалу в початковій та основній школі; б) проаналізувати причини орфографрічних помилок учнів, форми роботи над ними; в) виявити умови ефективного взаемозв'язку принципів дидактики в навчанні орфографої, розробити методи і прийоми їх реалізації в навчальний процес; г) визначити оптимальні способи структурування навчального матеріалу з української мови з урахуванням рівня його складності та значення для вироблення практичних умінь і навичок; д) проаналізувати та узагальнити досвід навчання української мови в сучасній школі.

Методи / Methods. Для реалізації поставлених завдань використано такі методи дослідження: a) теоретичні: аналіз і синтез лінгвістичної, психолого-педагогічної та лінгводидактичної літератури; б) теоретичне осмислення і узагальнення передового досвіду роботи вчителів української мови (початкової та основної ланки); в) емпіричні: спостереження й аналіз уроків, бесіда з учителямисловесниками; г) аналіз учнівських робіт.

Результати / Results. Дотримання дидактичних принщипів у навчанні особливо важливе під час засвоєння насамперед мовних норм, зокрема орфографічних, оскільки учневі необхідно запам'ятати велику кількість правил та слів-винятків, написання яких треба запам'ятати. Крім того, грамотне письмо потребуе вмінь правильно співвідносити звуки і букви, уяснити випадки розбіжності між орфоепією і орфографіею. Діти не завжди вміють застосовувати правило на практищі, що є однією 3 причин низької грамотності. Додержання загальнодидактичних принщипів сприяе виробленню знань, допомагає свідомо, в певному порядку набути необхідних умінь і навичок (Біляев О., 2005).

У визначенні, доборі і структуруванні мовного матеріалу у навчанні, крім принципів активності, свідомості й самостійності, слід керуватися принщипами наступності i перспективності, систематичності, послідовності, доступності тощо. Їх реалізація зумовлена дотриманням таких вимог:

1) враховувати досягнення сучасної лінгвістичної науки (принщип науковості);

2) подавати матеріал у стрункій логічній послідовності (принцип послідовності);

3) враховувати під час добору і структурування навчального матеріалу, а також вибору форм i 
методів роботи вікові особливості учнів, рівень їхньої загальної і мовної підготовки (принщип доступності);

4) спиратися на знання, здобуті учнями в попередніх класах, і готувати їх до усвідомленого сприйняття матеріалу, що вивчатиметься згодом (принщипи наступності та перспективності).

5) пов'язувати теоретичні відомості з мовленневою практикою учнів (принцип зв'язку теорії 3 практикою).

Одна з основних вимог теорії навчання - дотримання принципу науковості, за яким зміст шкільного курсу української мови має відповідати найновішим досягненням теорії, поняттям, явищам і фрактам лінгвістичної науки (Біляєв, О. М., Мельничайко, В. Я. та ін., 1987).

Принцип послідовності передбачае здійснення процесу навчання за певною системою. Він реалізуеться насамперед у програмі і підручниках, а також у різних формах тематичного планування, коли вчитель встановлюе порядок вивчення окремих розділів, тем, кількість годин на теми, поступовість виконання теоретичних і практичних робіт, повторення і контроль за ступенем засвоення навчального матеріалу, що допомагає логічно пов'язати кожну частину виучуваного матеріалу так, аби просте передувало складному, добре засвоєне - невідомому, наступне було продовженням попереднього і випливало з нього, доповнювало його.

Для усвідомленого засвоєння правил та економії часу на практичні вправи потрібно використати набуті учнями знання в початкових класах так, щоб вони стали опорою під час опрацювання навчального матеріалу в наступних класах. Відомо, що краще навчаеться той, хто виніс із початкових класів глибокі, міщні знання, на які можна опертися. Якщо вчитель зуміє вміло пов'язати вивчене раніше 3 новим матеріалом, то без особливих труднощів встановлюються асоціації між знаним i невідомим, засвоєння дефініцій буде міцним, глибоким і свідомим.

Як підтверджують бесіди 3 учителями, спостереження й аналіз уроків, не всі педагоги дотримуються принщипів наступності і перспективності в навчальному процесі, часто ними нехтують. Переважно новий матеріал вивчається без актуалізації знань, тобто не проводиться робота в напрямку від відомого до невідомого, від легкого до важкого, а вся тема подається як щось нове; не накреслюються перспективні зв'язки 3 наступними розділами. Загалом це призводить до того, що дорогощінний час уроку витрачається на з'ясування вже відомого, внаслідок чого менше часу залишається на закріплення нових, більш складних орфографічних правил, на відомості, які потребують докладного вивчення.

Отже, повторення необхідне, але проводити його слід за допомогою спеціально дібраних вправ, згрупованих за правилами, на складнішому лексичному матеріалі, щоб уникнути того відчутного розриву, який трапляеться у роботі вчителів початкової та основної школи і негативно впливає на процес навчання, перешкоджає формуванню мовної і мовленнєвої культури, вдоскналенню грамотності учнів.

Як відомо, слово «грамотність» уживається в широкому і вузькому розумінні. Бути грамотним у широкому розумінні - значить володіти всіма багатствами мови, правильно писати і висловлюватись, творити власний текст. Про грамотність у вузькому розумінні говоримо, коли маемо на увазі писемне мовлення, що відповідае нормам української орфографії та пунктуащії (Яворська С., 2015).

Розглянемо актуалізацію знань учнів у комплексі (опора на всі необхідні засвоені раніше правила) на прикладі вивчення теми «Апостроф» в 5 класі за чинною програмою (Яворська С., 2015).

У початкових класах з орфограмою апостроф діти вже ознайомились і деякі ії види засвоїли,

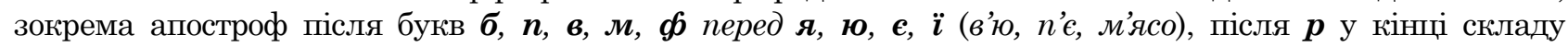
(матір'ю, міжсір'я, бур'ян); після префіксів, що закінчуються на приголосний, перед я, ю, $\boldsymbol{e}, \ddot{\boldsymbol{i}}$ (без'язикий, від”'зз)).

У 5-му класі знання з цієї теми закріплюються, поглиблюються, поповнюючись новими правилами:

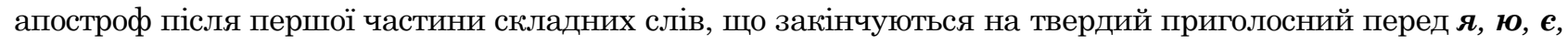
$\ddot{\boldsymbol{i}}$ (дит'ясла, пів'яблука); у слові Лук'ян і похідних від нього; а також випадки, коли апостроф не пишеться: 1) якщо перед губним звуком е приголосний (крім p), який належить до кореня (мавпячий, різьбяний, але: торбб'яний, черв'як, верб’я); 2) у словах іншомовного походження, де букви $\boldsymbol{я}, \boldsymbol{ю}, \boldsymbol{e}, \ddot{\boldsymbol{i}}$ дещо пом'якшують губний: бюро, пюпітр.

Однак навіть не всі студенти легко засвоюють правило, коли апострофр не пишеться, і в письмових роботах допускають помилки у словах типу тьляний, морквяний, та ін. I теоретично обгрунтувати таке написання також не можуть, оскільки забули чи колись неміцно засвоїли відповідне правило. А п’ятикласники й поготів відчувають великі труднощі, опрацьовуючи цю орфограму.

Для того щоб засвоєння теми було найефективнішим, не марнувався час на вивчене в початковій школі, насамперед треба повторити і закріпити з учнями відомості про губні, тверді і м'які звуки, звукове значення букв $\boldsymbol{\boldsymbol { s }}, \boldsymbol{ю}, \boldsymbol{\epsilon}, \boldsymbol{i}$, складні слова, структуру слова, зокрема префікси, а потім виконувати вправи. Тема «Апостроф» пов'язана з багатьма розділами мови - «Фонетикою», «Будовою слова», «Словотвором», «Орфоепіею». I якщо не відтворити необхідні знання, навчальний матеріал учні 
опанують поверхово, неміцно.

Актуалізація опорних знань потребуе від учителя застосування ефрективних методів і прийомів роботи: розповідь, різні види бесід, спостереження, метод вправ, робота з підручником, інтерактивні форми, самостійна робота, фонетичний, морфемний, словотвірний аналізи, дослідженнятощо. Вони залежатимуть від знань учнів, складу класу, умов, у яких педагог проводитиме урок. Проте одними практичними чи усними вправами тут не обійтися, перед вивченням теми уроку слід виявити теоретичні знання.

Можна пропедевтичну роботу проводити завчасно, тобто за два-три уроки до вивчення теми «Апостроф», а на самому занятті приділити увагу повторенню відомостей із початкової школи, вправам із орфоепії. Доцільно тренувати учнів у правильній вимові слів типу бур'ян, буряк, буряний, солов $і$, крякати, кур'єр, наголошуючи, що спільним між усіма видами ціеї орфограми $е$ позначення твердості приголосного перед м'яким звуком $[\check{u}]$, який разом із голосними $[\boldsymbol{a}],[\boldsymbol{y}],[\boldsymbol{e}],[\boldsymbol{i}]$ позначається буквами $\boldsymbol{\boldsymbol { s }}$, $\boldsymbol{ю}, \boldsymbol{\epsilon}, \ddot{\boldsymbol{i}}$. Доречним тут буде фонетичний аналіз слів, запис їх у фонетичній транскрипщії: [пйуть], [бурйан], [бур'ак]. Якщо у класі е смартдошка, учитель матиме змогу зекономити час на урощі, спроектувавши деякі вправи через компютер на екран. Лише переконавшись, що учні повторили і закріпили добре матеріал початкових класів, учитель може поповнювати їхні знання новими правилами.

У побудові методики вивчення орфографії обов'язково слід брати до уваги вікові психологічні особливості школярів, рівень їх підготовленості (забезпечувати принцип доступності). Нерідко частина учнів 5-го класу з перших тижнів навчання втрачае інтерес до школи, відстае з багатьох предметів, особливо з мови, помітно гіршае поведінка, почерк, ставлення до ведення зошитів, користування підручниками. Інколи у цьому звинувачують класовода: не зумів навчити дітей. Та насправді причина в іншому.

У 1-4-х класах усі предмети вів один педагог, який знав можливості своїх вихованщів, здібності кожного, зважав у роботі на їхні індивідуальні особливості. Однак, коли учень після тримісячних канікул приходить у 5-й клас, усе вивчене він пам'ятає слабо, до того ж кожен предмет викладає новий учитель, який не знає дітей, не враховуе ступеня їх підготовленості, умінь і знань.

Як підтверджують спостереження, на жаль, в освіті склалася така ситуащія, що частина вчителів старших класів не знає ні програм, ні підручників, ні методики роботи з учнями початкових класів і працювати 3 п'ятикласниками починае нераціонально: часто на початку навчального року пропонуються складні диктанти, текст, насичений орфограмами; непосильні за змістом і обсягом завдання, а оцінюють роботи вже за нормами п'ятого класу. Та й підручники для основної школи значно складніші, ніж ті, за якими вчаться учні початкових класів. Тому деякі школярі швидко втрачають інтерес до навчання, не вірять, що можуть добре вчитися, їм важко розібратися у тій великій кількості домашніх завдань, які потрібно виконати.

Для уникнення џього слід старанно добирати методи і прийоми роботи, не дорікати дітям, що вони нічого не знають, нічому не навчилися в початкових класах. Усі п'ятикласники можуть навчатися успішно і з перших днів, якщо вчитель дотримуватиметься принщипу наступності у викладанні. Це підтверджують педагоги, що мають великий досвід роботи, добре знають програму 1-4-х класів, методику роботи з дітьми.

Учителям, які не працювали в початковій школі, перед початком навчального року варто уважно ознайомитися з програмою, підручниками для 2-4-х класів, щоб у 5-му класі перед вивченням систематичного курсу мови провести повторення найважливіших і складних розділів, а потім спиратися на здобуті раніше знання. Досвідчені словесники, знаючи, що в наступному навчальному році працюватимуть у 5-х класах, відвідують уроки мови в 4-х класах, знайомляться з учнями (а діти звикають до них), надають учителям початкових класів методичну допомогу.

На початку навчального року в 5-му класі слід написати диктант, аби встановити рівень грамотності учнів, а потім зробити класифікацію помилок, завести картку на школярів, які виявили низьку грамотність. Якщо е потреба, дібрати індивідуальні завдання і після цього розпочати на уроках повторення недостатньо засвоєного. На поновлення в пам'яті теоретичного матеріалу не обов'язково відводити спеціальний урок. Повторювати можна і під час бесіди, і під час мовного аналізу, а також виконуючи вправи i роботу над помилками, допущеними в письмових роботах. Дітям можна запропонувати списати речення, вставити пропущені букви, обтрунтувати свій вибір; виконати вправу творчого характеру. У кожному випадку значну увагу слід приділяти розвитку мовленневих умінь і на тексті формувати грамотне письмо.

Постійне повторення матеріалу за початкові класи, раціональний розподіл часу на вивчення вже знайомих учням тем, приділення більшої уваги новим, складним правилам для кращого їх розуміння, осмислення, вибір форм і методів роботи створюе можливості для втілення в навчальний процес принщипу доступності.

У навчанні мови багато важить продуманий добір практичних завдань для закріплення 
теоретичного матеріалу, тобто дотримання принципу зв'язку теорії з практикою, оскільки «без вправ заняття звелися б до голої теорії» (Текучев О., 1980, с .80). Позитивні результати дае систематична активізація словника учнів. Як відомо, учні початкових класів засвоюють написання великої кількості слів, які не перевіряються правилами. Хоча програма середньої школи не передбачае лексичного мінімуму в кожному класі, проте цю роботу слід продовжити, щоб виробити у школярів навички грамотного письма під час створення текстів різного виду. Для цього потрібно скласти списки слів, найбільш складних з погляду орфографії. Працювати над ними необхідно постійно: вводити у тексти диктантів, переказів, у речення для граматичного розбору, у вправи на закріплення. Слова, написання яких треба запам'ятати, слід розподілити за семестрами; найскладнішим приділити найбільше уваги: зробити аналіз за будовою, записати на таблиці і періодично вивішувати в класі, складати з ними речення, зв'язне висловлення. На завершальному етапі засвоєння їх перевірити за допомогою програмованого контролю знань, тестів, диктантів тощо.

Ефективними е вправи зі словниками, працюючи з якими діти не лише закріплюють потрібну орфограму, а й з'ясовують лексичне значення слова і при цьому набувають певних навичок самостійної роботи, вчаться працювати з довідковою літературою.

Учитель хвилини уроку мае використати продуктивно, до кожного заняття скласти докладний конспект, дібрати відповідний ілюстративний матеріал, добре продумати методи і прийоми роботи на кожному етапі, врахувати їх ефективність, дбати про те, щоб учні не мали часу нудьгувати, а були завантажені роботою посильною і цікавою, яка потребуе від них активного мислення.

Передбачені програмою орфограми, вивчені в початкових класах частково, становлять переважну більшість. Це буквені, апостроф, пропуски (написання окремо), контакти (написання разом). До них належить і орфограма-рисочка (перенос слів). У 5 -6-х класах необхідно систематично повторювати відомості про неї і закріплювати навички правильно переносити слова із рядка в рядок. Щоб домогтися міџного засвоення теми, вчитель має не лише повторити й закріпити вивчене в початкових класах, а й подбати про поглиблення знань шляхом показу зв'язку переносу слів із фонетичними та морфологічними особливостями мови, зокрема під час вивчення складоподілу, голосних, приголосних звуків, будови слова. Це створюе підгрунтя для свідомого засвоєння правила (Біляєв О., 2005).

Для закріплення мовного матеріалу, вироблення якостей читання, особливо в початкових класах, розвитку мовлення учнів слід використовувати тексти: прислів'я, приказки, вірші, різні види диктантів, переказів, фррагменти літературних творів, художніх мініатюр тощо. Усі тексти (i граматичні, і стилістичні) мають добиратися з урахуванням знань і вікових особливостей учнів. Виконання їх сприяе не тільки закріпленню теоретичних відомостей, а й розвитку мислення, мовлення, самостійності учня. Збагачення культури усного і писемного мовлення має бути одним із першочергових завдань, які розв'язуе вчитель на уроці. Пам'ятаємо, що дитина приходить до школи, уже добре володіючи мовою на рівні її зв'язків зі світом. Усі вади у мові дітей, крім артикулящійних, випливають із рівня їх розвитку. Отже, подальше опанування мовою повинно здійснюватись через розширення і збагачення цих едностей (Божович О., 1979).

Практика підтверджуе, що навіть ідеальне знання правил дае дуже скромні результати в навчанні. І учень, і доросла людина у власному правописі переважно в писемному мовленні керуються не стільки зводом правил, скільки інтуїтивним услухуванням у свою внутрішню мову. Тому завдання вчителя - розвинути цей природний дар володіння мовою, навчити їх слухати себе, вслухатись у себе. Нині школа мусить навчити учнів мистецтву порозуміння, сорормувати в них навички користуватися певними комунікативними моделями відповідно до мети спілкування, зумовленої як внутрішніми потребами, так і зовнішніми обставинами. Це різноманітні варіанти комунікативних ситуацій: у школі, транспорті, в місцях відпочинку і розваг, на вулищі, в театрі, в магазині і навіть удома.

Відомо, що найпоширенішою формою людського спілкування є діалог, який відбувається на кожному уроці між учнями, вчителем і учнями. Спочатку це бесіда за наперед визначеними вчителем запитаннями, а далі учні самі вчаться розробляти варіанти діалогів на задану тему. Це привчає мати власне ставлення до слова, розуміти, що вживання будь-якого розділового знака - коми, тире тощо залежить не від правила, а від наших емоцій, душевного стану, бажань. На уроці важливе місце має зайняти розроблення невеличкого діалогізованого твору, оскільки така робота дае можливість зрозуміти і освоїти емоційну виражальну функцію мови.

Обговорення / Discussion. Проблема підвищення грамотності учнів була предметом дослідження не одного покоління методистів, педагогів і психологів.

Важливими в контексті проблеми формування мовно-мовленневих компетентностей в учнів початкової та основної школи є дослідження вітчизняних і зарубіжних учених із психології, педагогіки, лінгвістики та лінгводидактики з питань взаемозв'язку мовленневої та розумової діяльності людини (Д. Богоявленський, О. Божович, Л. Виготський, І. Синиця, Л. Проколіенко та ін.), співвідношення мови й мовлення (А. Алексюк, Ю. Бабанський, І. Олійник, О. Біляев, В. Бадер, О. Текучов та ін.), формування мовленневої компетентності учнів (В. Бадер, З. Бакум, М. Вашуленко, О. Горошкіна, 
С. Караман, О. Караман, Ю. Бабанський, О. Біляєв, Е. Палихата та ін.), педагогічні та методичні теорії свідомого формування усного і писемного мовлення учнів (М. Николин, М. Пучковський, Л. Симоненкова, I. Хом'як, О. Хорошковська, С. Яворська та ін.), лінгводидактичні особливості застосування форм, методів, засобів, технологій навчання (О. Біляев, О. Горошкіна, І. Дроздова, Т. Груба, Г. Дідук-Ступ’як, О. Кучерук, О. Потапенко, Л. Попова, С. Яворська та ін.).

У наукових і методичних працях висвітлено загалом часткові, проте дуже важливі питання, а також загальні питання, що розкривають вихідні, принципові положення організації занять з мови у школі. У дослідженнях науковці значну увагу акцентують на розв'язанні різних питань методики навчання української мови, однак аналізована нами проблема представлена у різних аспектах. Чіткої системи роботи з формування мовно-мовленневої компетентності учнів з української мови не визначено, а, як відомо, сформувати мовно-мовленневі компетентності - значить навчити учнів ефективно використовувати здобуті знання і навички у практичній діяльності. У навчанні мови недостатньо враховані психофізіологічні особливості учнів, підхід до розвитку мовлення учнів неправомірний: складні комунікативні вміння прагнуть сформувати на основі не досить міцних орфографрічних і пунктуаційних навичок, які е необхідним компонентом писемного мовлення. Це призводить до значної кількості помилок, що вкрай негативно впливають на психіку учнів.

Оскільки мовлення тісно пов'язане з мисленням і діяльністю людини, процес його вдосконалення ніколи не припиняеться. Будь-яка діяльність, у тім числі й навчальна, по-перше, вимагає відповідного оволодіння мовленням, а по-друге, осмислюеться через мову. Чітко окреслений змістовий компонент сприяе визначенню мовних знань та мовленневих умінь, які формуються у процесі практичної діяльності.

Висновки / Conclusions. Пропонована методика грунтуеться на використанні чинних технологій навчання, системи вправ і завдань, організації цілеспрямованого повторення теоретичного матеріалу 3 мови та органічному зв'язку орфографічних занять з розвитком мовлення учнів, вироблення в них комунікативних умінь і навичок у процесі вивчення мовних норм.

Знання учнів будуть поглиблюватись i зміцнюватися, мовно-мовленневі навички удосконалюватись, а правила легко засвоюватися за умови вмілого застосування принципів дидактики, що в сукупності активізуе навчальну діяльність учнів, підводить до розуміння ролі взаемозв'язку різних тем, сприяе міцності знань, розвивае логічну пам'ять, робить навчання цікавим. Різні форми, методи і прийоми роботи на уроці забезпечать оволодіння дітьми всіма типами усного i писемного мовлення, забезпечать формування мовних і мовленневих компетентностей.

Перспективним є розроблення системи подальшого формування мовної i мовленневої компетентностей, удосконалення вмінь і навичок учнів, спрямованих на підвищення грамотності, у процесі вивчення лексики, фразеології, самостійних і службових частин мови.

Список використаних джерел і літератури/References:

1. Біляев, О. М. (2005). Лінгводидактика рідної мови. Київ: Генеза / Biliaiev, О. М. (2005). Linhvodydaktyka ridnoi movy [Linguadidactics of the Native Language: a Teaching Guide]. Kyiv: Geneza [in Ukrainian]

2. Божович, Е. Д. (1979). Психологические особенности развития личности подростка. Москва: Знание / Bozhovych, E. D. (1979). Psykholohycheskye osobennosty razuytyia lychnosty podrostka [Psychological Peculiarities of the Development of a Teenager's Personality]. Moscow: Znanye [in Russian]

3. Біляев, О. М. \& Мельничайко, В. Я. та ін. (1987). Методика вивчення української мови в школі. Київ: Радянська школа / Biliaiev, O. M. \& Melnychaiko, V. Ya., et al (1987). Metodyka vyvchennia ukrainskoi movy v shkoli [Methods of Learning the Ukrainian Language at School]. Kyiv: Radianska shkola [in Ukrainian]

4. Текучев, А. В. (1980). Методика русского языка в средней школе (3-е изд.). Москва: Просвещение / Tekuchev, A. V. (1980). Metodika russkogo yazyka v srednej shkole [Methodology of the Russian Language at Secondary School]. (3rd ed.). Moscow: Prosveshhenie [in Russian]

5. Ушинський, К. Д. (1949). Вибрані педагогічні твори (Т. 7). Київ: Радянська школа / Ushynskyi, K. D. (1949). Vybrani pedahohichni tvory [Selected Pedagogical Works]. (Vol. 7). Kyiv: Radianska shkola [in Ukrainian]

6. Яворська, С. Т. (2015). Методика навчання орфбографії. (2-е вид., змінене, випр. і доповн.). Київ: Аграр Медіа Груп / Yavorska, S. T. (2015). Metodyka navchannia orfohrafii [Methods of Teaching Orthography]. (2nd ed., rev. ed.). Kyiv: Ahrar Media Hrup [in Ukrainian]

Дата надходження статті: «10» квітня 2018 p.

Стаття прийнята до друку: «14» травня 2018 р.

Яворська Стефанія - професор кафедри української мови Киӥвського університету імені Бориса Грінченка, доктор педагогічних наук, професор

Yavorska Stefaniia - professor of the Ukrainian Language Department of Borys Grinchenko Kyiv University, doctor of pedagogical sciences, professor

Цитуйте ию статтю як:

Яворська, С. (2018). Єдність загальнодидактичних принципів у процесі формування мовно-мовленневих компетентностей в учнів початкової та основної школи. Педагогічний дискурс, 24, 57-62.
Cite this article as:

Yavorska, S. (2018). The Unity of General Didactic Principles in the Process of Formation Linguistic and Speech Competences with Students of Primary and Secondary School. Pedagogical Discourse, 24, 57-62. 